\title{
Distribution, fluxes and decadal changes of nutrients in the Jiulong River Estuary, Southwest Taiwan Strait
}

\author{
YAN XiuLi ${ }^{1}$, ZHAI WeiDong ${ }^{1,2 *}$, HONG HuaSheng ${ }^{1}$, LI Yan $^{1}$, GUO WeiDong ${ }^{1} \&$ \\ HUANG Xiao ${ }^{1}$ \\ ${ }^{1}$ State Key Laboratory of Marine Environmental Science, Xiamen University, Xiamen 361005, China; \\ ${ }^{2}$ Key Laboratory for Ecological Environment in Coastal Areas (State Oceanic Administration), National Marine Environmental Monitoring \\ Center, Dalian 116023, China
}

Received August 15, 2011; accepted January 10, 2012; published online April 12, 2012

\begin{abstract}
The Jiulong River Estuary (JRE) is a typical subtropical macro-tide estuary on the southwest coast of the Taiwan Strait (TWS), which has been greatly impacted by human activities over the past 30 years. To understand nutrient dynamics and fluxes under such a heavy background of anthropogenic perturbation, eight cruises were conducted from April 2008 to April 2011, covering both wet (May to September) and dry (October to April next year) seasons. Nutrient concentrations were very high for the freshwater end-member in the upper reach of the JRE (nitrate $\left(\mathrm{NO}_{3}-\mathrm{N}\right): 120-230 \mu \mathrm{mol} \mathrm{L}{ }^{-1}$; nitrite $\left(\mathrm{NO}_{2}-\mathrm{N}\right): 5-15 \mu \mathrm{mol} \mathrm{L}^{-1}$; ammonium $\left(\mathrm{NH}_{4}-\mathrm{N}\right.$ ): $15-170 \mu \mathrm{mol} \mathrm{L}{ }^{-1}$; soluble reactive phosphorus (SRP): $1.2-3.5 \mu \mathrm{mol} \mathrm{L}^{-1}$; dissolved silicate (DSi): $200-340 \mu \mathrm{mol}$ $\left.\mathrm{L}^{-1}\right)$. In dry seasons, concentrations of these nutrients were higher than in wet seasons. Nitrate was the dominant chemical species of dissolved inorganic nitrogen (DIN), with percentages of $67 \%-96 \%$ in wet seasons and $55 \%-72 \%$ in dry seasons. Distributions of $\mathrm{NO}_{3}-\mathrm{N}$ and DSi against salinity were nearly constant during all cruises, and showed generally conservative mixing behaviors in the estuary $\left(1<\right.$ Salinity<32). The concentrations of SRP varied within a narrow range of $1.0-2.0 \mu \mathrm{mol} \mathrm{L} \mathrm{L}^{-1}$ in low/middle salinity areas, and they were quickly diluted by relatively oligotrophic near-shore seawater in the high salinity region. Based on a temporally high-resolution water discharge dataset, riverine fluxes of DIN, SRP and DSi into the JRE were calculated at $34.3 \times 10^{3} \mathrm{t} \mathrm{N}$ $\mathrm{a}^{-1}, 0.63 \times 10^{3} \mathrm{t} \mathrm{P} \mathrm{a}^{-1}$ and $72.7 \times 10^{3} \mathrm{t} \mathrm{Si} \mathrm{a}^{-1}$, respectively. In comparison, estuarine export fluxes of DIN, SRP and DSi from the JRE to the TWS were estimated at $34.8 \times 10^{3} \mathrm{t} \mathrm{N} \mathrm{a}^{-1}, 0.82 \times 10^{3} \mathrm{t} \mathrm{P} \mathrm{a}^{-1}$ and $71.6 \times 10^{3} \mathrm{t} \mathrm{Si} \mathrm{a}^{-1}$. The estuarine addition flux of SRP was independently estimated at $0.16 \times 10^{3} \mathrm{t} \mathrm{P} \mathrm{a}^{-1}$. In comparison with major world rivers, the Jiulong River shows a very high areal yield rate of $\mathrm{NO}_{3}-\mathrm{N}$. In comparison with historical datasets from 1980s-1990s, concentrations of $\mathrm{NO}_{3}-\mathrm{N}$ and SRP increased 2-3 times in upper/middle areas of the JRE, while DSi remained at the same level. The latter is much different from decadal nutrient changes in the Mississippi River and the Yangtze River/Estuary. Such nutrient changes may fundamentally contribute to recent red tide events in the JRE and adjacent Xiamen Bay.
\end{abstract}

Jiulong River Estuary, nutrients, flux, decadal change

Citation: Yan X L, Zhai W D, Hong H S, et al. Distribution, fluxes and decadal changes of nutrients in the Jiulong River Estuary, Southwest Taiwan Strait. Chin Sci Bull, 2012, 57: 2307-2318, doi: 10.1007/s11434-012-5084-4

Decadal increases in nutrients of nitrogen and phosphorus, along with decreases in dissolved silicate (DSi) concentration, have been widely reported in many large river basins in the world [1,2]. This could be a consequence of either global climate change or growing human activities (e.g. population growth, poultry/livestock culture, chemical fertilizer application, dam construction, and others), accompa-

*Corresponding author (email: wdzhai@126.com) nied by land-use/land-cover changes. For example, nitrate $\left(\mathrm{NO}_{3}-\mathrm{N}\right)$ and total phosphorus concentrations in the Mississippi River increased 3-4 times from 1950 to 2000, owing to a consistent increase in chemical fertilizer application [3]. In contrast, DSi decreased by $\sim 50 \%$ over the same period $[3,4]$. Similar nutrient changes have been reported in the Yangtze River, where dissolved inorganic nitrogen (DIN) and soluble reactive phosphorus (SRP) concentrations increased sharply from 1960 to 2000 [5,6], while DSi dropped from $130 \mu \mathrm{mol}$ 
$\mathrm{L}^{-1}$ in 1960 to $80 \mu \mathrm{mol} \mathrm{L} \mathrm{L}^{-1}$ in $1985[4,6,7]$. The major reasons for this are also related to chemical fertilizer application, population growth and dam construction $[5,6]$.

These changes have made significant environmental impacts on coastal ecosystems $[1,8]$, e.g. coastal eutrophication, frequent harmful algal bloom events, and seasonal hypoxia [1,9-11]. Therefore, variation in riverine fluxes of nutrients has been highlighted over the past 30 years, and is a major theme in the Land-Ocean Interactions in the Coastal Zone (LOICZ) program [8]. The synergistic effect between climate and land-use/land-cover change has been recently emphasized, since it may increase nutrient export fluxes from rivers into adjacent coastal zones $[12,13]$.

Jiulong River is the second-largest river in Fujian Province of southeast China, with a watershed area of 14741 $\mathrm{km}^{2}$ [14] and two major tributaries (i.e. North Stream and West Stream). Rapid economic development in this area during the past three decades has brought on significant anthropogenic perturbations. Both the use of chemical fertilizer and the number of livestock increased by $6-10$ times, and gross industrial output increased by 100 times in the watershed. Over the last 10 years, hundreds of cascade hydropower stations have been rapidly constructed along main and tributary channels of the two streams $[15,16]$. Meanwhile, large tracts of vegetated land have been converted to built lands [17]. A consequence of the combined effects of these factors is the emergence of aquatic eutrophication in the Jiulong River Estuary (JRE) [18]. However, only a few studies since the late 1990s have concentrated on nutrient dynamics in this estuary. Most qualified nutrient data in this estuary in the literature are from early surveys during 1962-1997 [19-31], which mainly cover the salinity range from 5 to 30 . Nutrient data is lacking in the low salinity area close to the river-estuary interface, and the high salinity area connected with the coastal waters. Thus, it is difficult to understand potential impacts of anthropogenic perturbation in the Jiulong River watershed on nutrient dynamics in the estuary, and eventually on adjacent coastal zones of the southwest Taiwan Strait (TWS).

We conducted eight cruises in the JRE and three in adjacent coastal waters, from April 2008 to April 2011. These cruises covered both wet seasons (May to September) and dry seasons (October to April next year). Our purpose is to characterize variations of spatial and temporal distributions of nutrients during their transport in this estuary. Changes of nutrient distributions and fluxes over past decades are also assessed by comparing this dataset with historical data. This comparison provides clear evidence of how estuarine nutrient dynamics respond to the continuous increase of human stresses, especially from the watershed.

\section{Materials and methods}

\subsection{Study area and sampling sites}

The JRE is along the southwest coast of the TWS. As a typ- ical subtropical macro-tide estuary, its water temperature ranges from 13 to $32^{\circ} \mathrm{C}$ and maximum tidal current speeds during spring tide are $>1.5 \mathrm{~m} \mathrm{~s}^{-1}$ in bottom waters and $>2.0$ $\mathrm{m} \mathrm{s}^{-1}$ at surface and middle levels [32]. The flushing time in the JRE has been estimated at 2-3 d [33].

Eight sampling cruises were carried out in the JRE during April, August, and November 2008, May and late June 2009, early July 2010, January and April 2011 (Figure $1(\mathrm{a})-(\mathrm{c}))$, covering full seasonal variations of water discharge (Figure 2). To get seawater end-member values, field surveys in adjacent seas were also made during November 2008, late June-early July 2009 and July 2010 (Figure 1(d)). The research vessels were Ocean I (2008-2009) and Ocean II (2010-2011) in the estuary, and Yanping II on the seas. Sampling sites are shown in Figure 1.

\subsection{Sampling and analyses}

Water samples were collected in the estuary from nearsurface and near-bottom depths using $5 \mathrm{~L}$ Niskin bottles (model QCCC-5, National Ocean Technology Center, China), onboard R/V Ocean I and R/V Ocean II. During the coastal surveys, water samples were obtained at 3 or 4 depths using a rosette sampler fitted with $8 \mathrm{~L}$ Go-Flo bottles, which were mounted with a Conductivity-TemperatureDepth/Pressure (CTD) unit (SBE917+, Sea-Bird Co., USA) onboard R/V Yanping II.

In the estuary, duplicate water samples were filtered onboard with $0.45 \mu \mathrm{m}$ cellulose acetate membranes. One of these was poisoned with $1 \%$ - $2 \%$ o chloroform and preserved at $4^{\circ} \mathrm{C}$ for $\mathrm{NH}_{4}-\mathrm{N}$ (ammonium) and DSi determination [34], while another was deep-frozen and kept at $-20^{\circ} \mathrm{C}$ for $\mathrm{NO}_{3}-\mathrm{N}, \mathrm{NO}_{2}-\mathrm{N}$ (nitrite) and SRP determination. Water samples for estuarine salinity measurements were sealed and kept at room temperature, until they were determined using a WTW TetraCon ${ }^{\circledR} 325$ probe based on conductivity measurements, with a precision of \pm 0.1 (practical salinity units). All these water samples were analyzed in the land-based laboratory.

During our coastal surveys, the CTD unit was used to measure temperature with a precision of $\pm 0.001^{\circ} \mathrm{C}$ and salinity with a precision of \pm 0.001 (practical salinity units). For the measurements of $\mathrm{NO}_{3}-\mathrm{N}, \mathrm{NO}_{2}-\mathrm{N}, \mathrm{SRP}$ and $\mathrm{DSi}$, single samples were taken onboard R/V Yanping II. They were filtered onboard, deep-frozen and preserved at $-20^{\circ} \mathrm{C}$ until determination in the land-based laboratory.

$\mathrm{NO}_{3}-\mathrm{N}$ and $\mathrm{NO}_{2}-\mathrm{N}$ were measured by reducing $\mathrm{NO}_{3}^{-}$to $\mathrm{NO}_{2}^{-}$with a Cd column, and then determining $\mathrm{NO}_{2}^{-}$using the standard pink azo dye spectrophotometric method [35]. $\mathrm{SRP}, \mathrm{DSi}$ and $\mathrm{NH}_{4}-\mathrm{N}$ were measured based on the standard phospho-molybdenum blue, silicon molybdenum blue and indophenol blue [36] spectrophotometric procedures, respectively. $\mathrm{NO}_{3}-\mathrm{N}, \mathrm{NO}_{2}-\mathrm{N}$, and SRP were determined using an AA3 Auto-Analyzer (Bran+Luebbe Co., Germany) [35], while $\mathrm{NH}_{4}-\mathrm{N}$ and DSi were measured using a Tri-223 


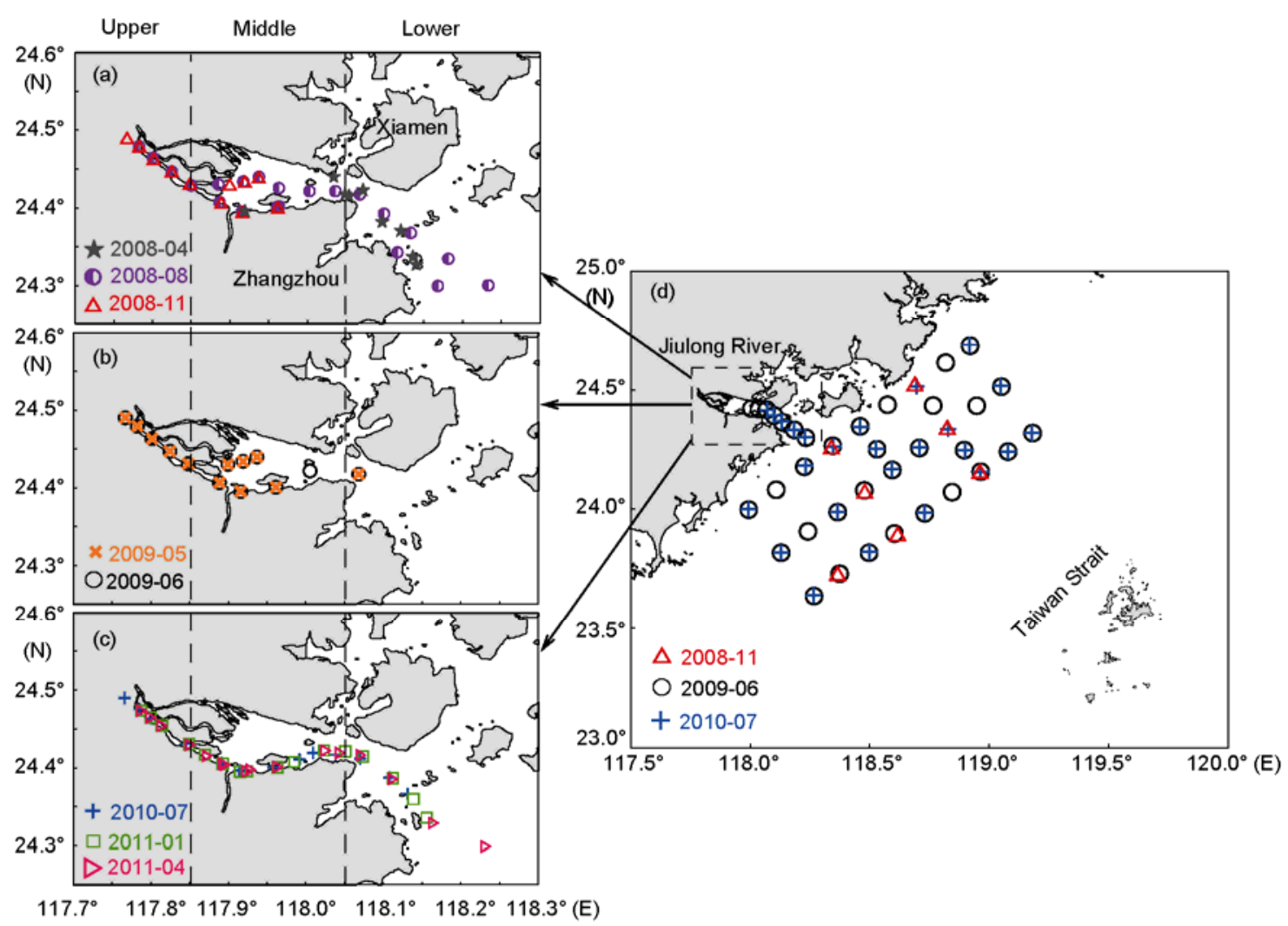

Figure 1 Area maps and sampling sites in the estuary and adjacent seas. (a) Estuary cruises in 2008; (b) estuary cruises in 2009; (c) estuary cruises in 2010-2011; (d) coastal cruises. Dashed vertical lines are boundaries of upper/middle/lower zones in the estuary.

continuous Auto-Analyzer [35]. Detection limits of the AA3 Auto-Analyzer were $0.1,0.04$ and $0.08 \mu \mathrm{mol} \mathrm{L}{ }^{-1}$ for $\mathrm{NO}_{3}-\mathrm{N}$, $\mathrm{NO}_{2}-\mathrm{N}$ and SRP/DSi, respectively. For the Tri-223 Auto-Analyzer, the detection limits were $0.5 \mu \mathrm{mol} \mathrm{L}{ }^{-1}$ for both DSi and $\mathrm{NH}_{4}-\mathrm{N}$. Samples with high nutrient concentrations were properly diluted before determination.

\subsection{Water discharge from Jiulong River}

During the period 2009-2011, daily water discharge data for the most downstream hydrologic stations (Pu-nan for North Stream and Zheng-dian for West Stream) were collected from the website of the Bureau of Hydrology, Ministry of Water Resources, China (http://xxfb.hydroinfo.gov. $\mathrm{cn})$. These two stations cover more than $80 \%$ of the area of the Jiulong River watershed [14]. The discharge data were summed up to obtain the yearly water discharge from the river into the estuary.

\section{Results and discussion}

\subsection{Hydrological conditions during investigation period}

During the investigation period, the varying magnitude and seasonal variations of water discharge from the watershed were basically consistent with the long-term mean (19612006) pattern of seasonal variation [14], although a certain degree of interannual variability was revealed (Figure 2). Water discharge generally peaks in May-June (the highest) and in August (second highest). Therefore, the four survey cruises from May through to August (August 2008, May and late June 2009, early July 2010) characterized the flood period, while the other four cruises (April 2008, November 2008, January and April 2011) represented dry seasons.

Figure 3(a) shows the spatial distribution of surface salinity along the surveying transect. A significant salinity front was persistently observed between $117^{\circ} 50^{\prime} \mathrm{E}$ and $118^{\circ} 03^{\prime} \mathrm{E}$, where freshwater at the upper reach of the JRE mixed with downstream saline waters and salinity increased from $<3$ to 20-29 (Figure 3(a)). In downstream areas of the JRE, salinity was between 20 and 33 .

In the adjacent coastal zone outside the JRE, different high-salinity coastal water masses were observable in various seasons. In summer (late June-early July 2009 and July 2010), surface salinity was between 32.5 and 33.5 , and bottom salinity was between 33.4 and 34.0. This indicates that in summer, the area outside the JRE was dominated by typical seawater from the northern South China Sea. In autumn (November 2008), however, much lower surface salinity of 30.4-32.0 was observed in the same region, although bottom salinity reached 33.4. This fact shows that a southing 


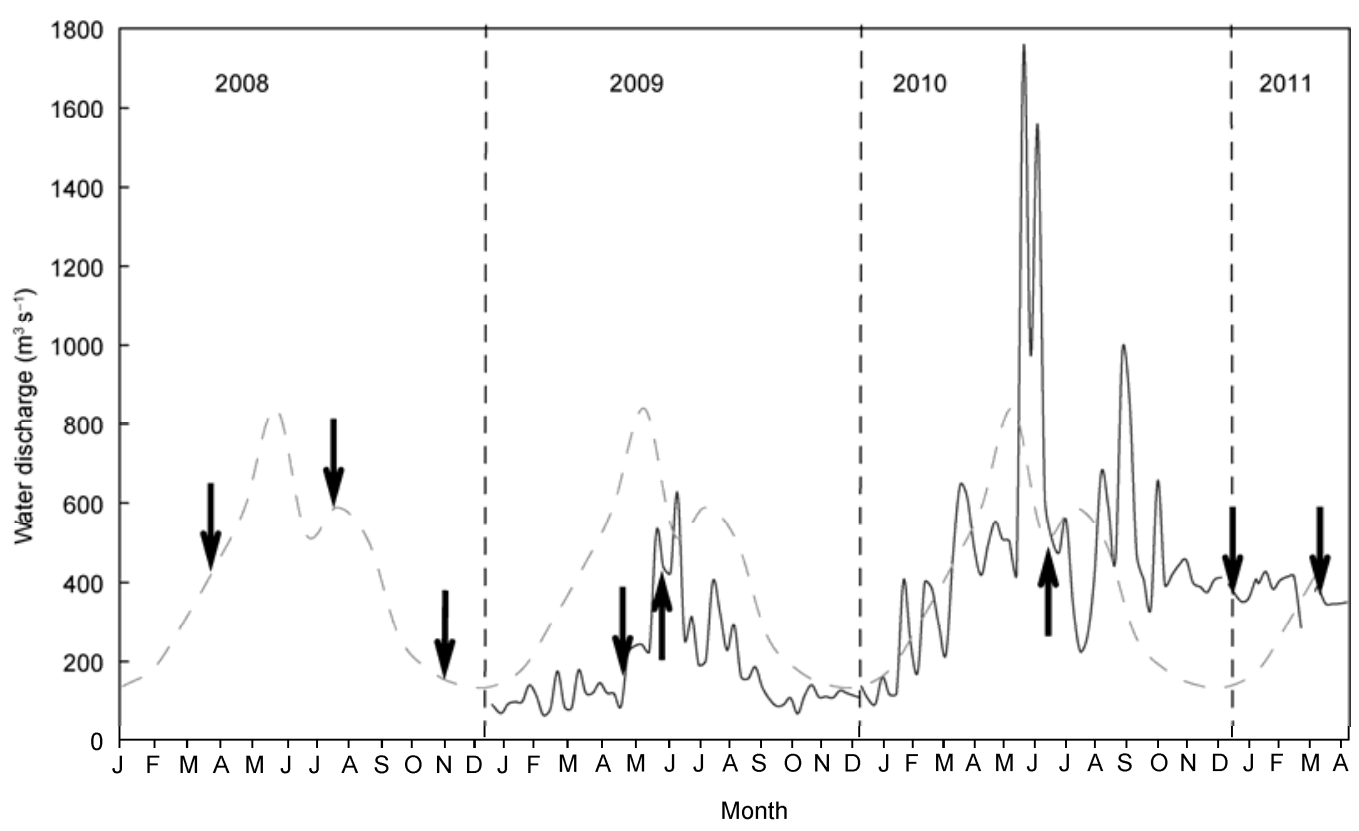

Figure 2 Interannual and seasonal variations of water discharge from Jiulong River. The dashed curve shows the long-term mean water discharge during 1961-2006 [14], while the real line curve denotes the water discharge from 2009 to 2011 . Arrows indicate those sampling surveys in the estuary.

winter coastal current may dominate the southwest TWS outside the JRE in autumn. Since the southing winter coastal current originates from the Yangtze Estuary, it is characterized by lower salinity than typical open ocean waters.

\subsection{Spatial distributions of nutrients in JRE and sea- sonal variations in the upper reach}

In the upper reach of the JRE, most nutrients were at very high levels (Figure 3). $\mathrm{NO}_{3}-\mathrm{N}$ ranged between 120 and 180 $\mu \mathrm{mol} \mathrm{L}{ }^{-1}$ in wet seasons, and $150-220 \mu \mathrm{mol} \mathrm{L}{ }^{-1}$ in dry seasons. $\mathrm{NH}_{4}-\mathrm{N}$ varied from $15-60 \mu \mathrm{mol} \mathrm{L} \mathrm{L}^{-1}$ in wet seasons to $60-170 \mu \mathrm{mol} \mathrm{L}{ }^{-1}$ in dry seasons. $\mathrm{NO}_{2}-\mathrm{N}$ concentrations were at a relatively low level of $5-15 \mu \mathrm{mol} \mathrm{L}{ }^{-1}$ in this region, only accounting for $2 \%-4 \%$ of DIN. DIN was usually $150-250$ $\mu \mathrm{mol} \mathrm{L} \mathrm{L}^{-1}$, although it reached a high range of 310-370 $\mu \mathrm{mol}$ $\mathrm{L}^{-1}$ in dry seasons during 2011. The concentration of SRP was generally between 1.2 and $2.2 \mu \mathrm{mol} \mathrm{L}{ }^{-1}$, although it increased to $2.8-3.5 \mu \mathrm{mol} \mathrm{L}^{-1}$ in April 2011. DSi was $250-340 \mu \mathrm{mol} \mathrm{L}^{-1}$ in dry seasons and $200-270 \mu \mathrm{mol} \mathrm{\textrm {L } ^ { - 1 }}$ in wet seasons.

In the middle part of the JRE, from the freshwater endmember to the seawater area, $\mathrm{NO}_{3}-\mathrm{N}$ decreased from $120-190 \mu \mathrm{mol} \mathrm{L}{ }^{-1}$ to $20-70 \mu \mathrm{mol} \mathrm{L}{ }^{-1}$. $\mathrm{NH}_{4}-\mathrm{N}$ remained at a relatively low level of $<30 \mu \mathrm{mol} \mathrm{L^{-1 }}$ in wet seasons, and declined from $60-120 \mu \mathrm{mol} \mathrm{L}{ }^{-1}$ to $5-20 \mu \mathrm{mol} \mathrm{L}{ }^{-1}$ in dry seasons. $\mathrm{A} \mathrm{NO}_{2}-\mathrm{N}$ maximum zone was observed in the middle part of the JRE, where $\mathrm{NO}_{2}-\mathrm{N}$ reached $17-30 \mu \mathrm{mol}$ $\mathrm{L}^{-1}$ in wet seasons during 2008-2009 and 15-20 $\mu \mathrm{mol} \mathrm{L}^{-1}$ in dry seasons of 2008. Similar to $\mathrm{NO}_{3}-\mathrm{N}$, DIN declined from $310 \mu \mathrm{mol} \mathrm{L}{ }^{-1}$ in the upper reach to $50 \mu \mathrm{mol} \mathrm{L}{ }^{-1}$ in seawaters. In this region, SRP was slightly lower than in the upper reach.
However, DSi decreased greatly, from $200-300 \mu \mathrm{mol} \mathrm{L}^{-1}$ in the upper reach to $30-100 \mu \mathrm{mol} \mathrm{L}{ }^{-1}$ in seawaters.

In the lower part of the JRE, low levels of $\mathrm{NO}_{3}-\mathrm{N}$, DIN and DSi $\left(<10 \mu \mathrm{mol} \mathrm{L}{ }^{-1}\right)$ were observed around the estuary mouth. SRP still ranged between $1.0-1.5 \mu \mathrm{mol} \mathrm{L} \mathrm{L}^{-1}$ in dry seasons, although its concentrations were $<1.0 \mu \mathrm{mol} \mathrm{L}^{-1}$ in seawater areas during wet seasons.

In the adjacent southwest TWS outside the JRE, surface nutrients were generally at very low levels. During summer (late June 2009 and early July 2010), nearshore surface DIN, SRP and DSi were lower than $4 \mu \mathrm{mol} \mathrm{L}{ }^{-1}, 0.4 \mu \mathrm{mol} \mathrm{L}{ }^{-1}$ and $10 \mu \mathrm{mol} \mathrm{L}{ }^{-1}$, respectively, while most of the offshore surface nutrients were below detection limits. In autumn (November 2008), surface DIN, SRP and DSi were determined as $12 \pm 5.0 \mu \mathrm{mol} \mathrm{N} \mathrm{L} \mathrm{N}^{-1}, 0.51 \pm 0.21 \mu \mathrm{mol} \mathrm{P} \mathrm{L}^{-1}$ and $10 \pm 4.8$ $\mu \mathrm{mol} \mathrm{Si} \mathrm{L}{ }^{-1}(n=6)$, respectively.

Generally, the upper reach of the JRE was characterized by high nutrient levels. This is a result of riverine input, i.e. the freshwater end-members were determined. In this region, most nutrients varied within a relatively narrow concentration range, although $\mathrm{NH}_{4}-\mathrm{N}$ varied considerably. The middle part of the JRE was the most dynamic region; it was dominated by estuarine mixing processes and therefore most nutrients varied greatly. In the lower JRE, the lowest levels of nutrients were found, under the influence of relatively oligotrophic coastal seawaters.

Table 1 summarizes the freshwater end-member concentrations of all nutrient parameters during the surveys. Combined with Figure 4, Table 1 shows that there were some seasonal variations in the freshwater end-members of the JRE. In general, most nutrient concentrations were higher in 

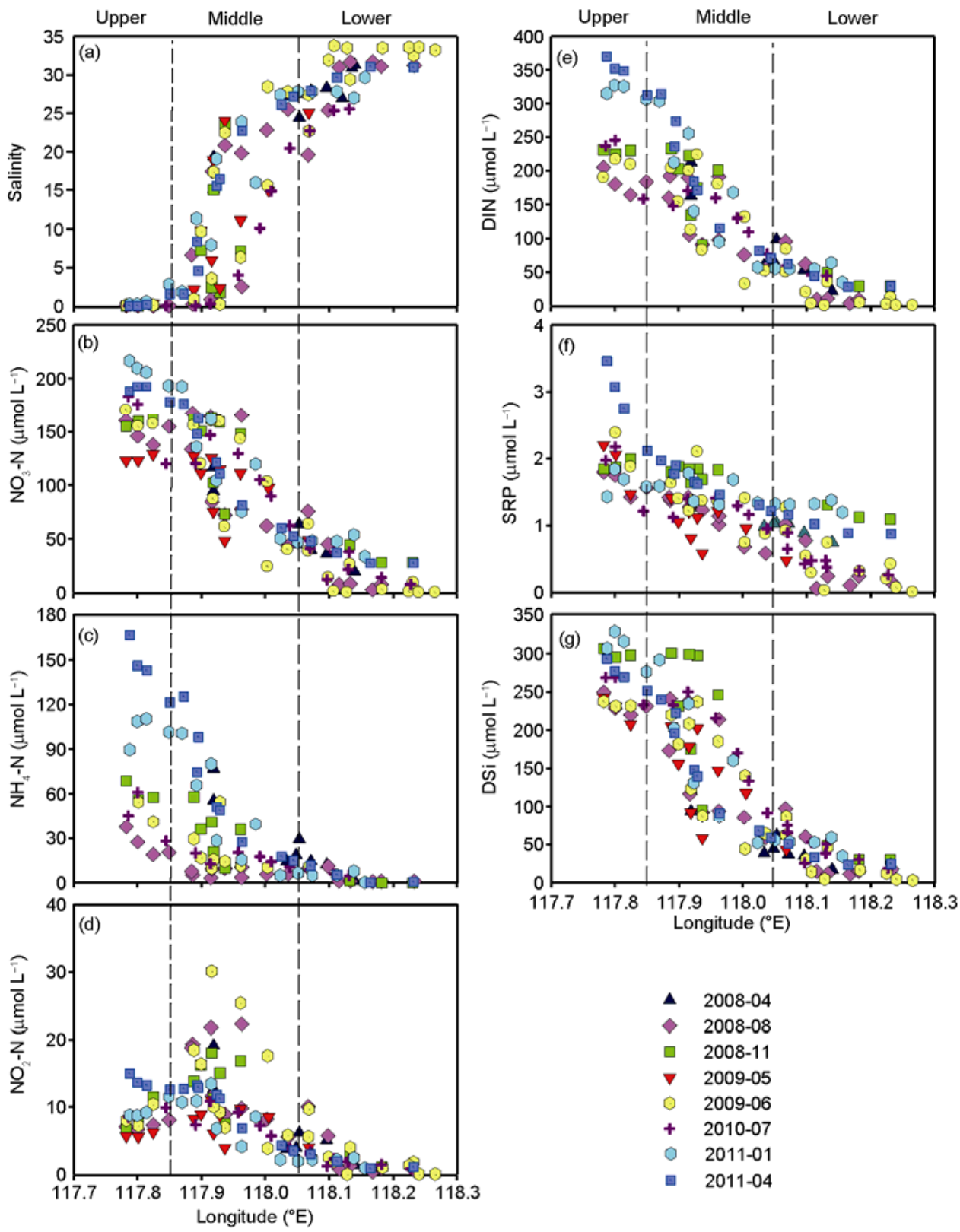

Figure 3 Spatial distributions of surface salinity, $\mathrm{NO}_{3}-\mathrm{N}, \mathrm{NH}_{4}-\mathrm{N}, \mathrm{NO}_{2}-\mathrm{N}$, DIN, SRP, and DSi in the JRE. Broken vertical lines are similar to those in Figure 1.

Table 1 Nutrient concentrations at freshwater end-members (Unit: $\left.\mu \mathrm{mol} \mathrm{L})^{-1}\right)^{\mathrm{a}}$

\begin{tabular}{|c|c|c|c|c|c|c|}
\hline Cruise & $\mathrm{NO}_{3}-\mathrm{N}$ & $\mathrm{NO}_{2}-\mathrm{N}$ & $\mathrm{NH}_{4}-\mathrm{N}$ & DIN & SRP & DSi \\
\hline 2008-08 & 156.5 & 6.8 & 36.4 & 199.7 & 1.87 & 233.4 \\
\hline 2008-11 & 152.8 & 6.9 & 69.1 & 228.8 & 1.81 & 306.0 \\
\hline 2009-05 & 124.0 & 5.4 & N/A & N/A & 2.06 & 238.8 \\
\hline 2009-06 & 173.7 & 8.2 & 41.3 & 223.2 & 2.38 & 240.4 \\
\hline 2010-07 & 174.8 & 8.8 & 41.3 & 224.9 & 1.80 & 245.4 \\
\hline 2011-01 & 216.7 & 8.8 & 98.0 & 323.5 & 1.63 & 313.0 \\
\hline 2011-04 & 189.4 & 14.4 & 156.5 & 360.3 & 3.29 & 284.8 \\
\hline
\end{tabular}

a) N/A means no data.

dry seasons than in wet seasons. It is worth noting that a storm-induced flood occurred just before our early July 2010 cruise, during which real-time water discharge was
1-2 times greater than in June 2009 (Figure 2). However, the determined freshwater end-member concentrations of nutrients during the two cruises remained at about the same 

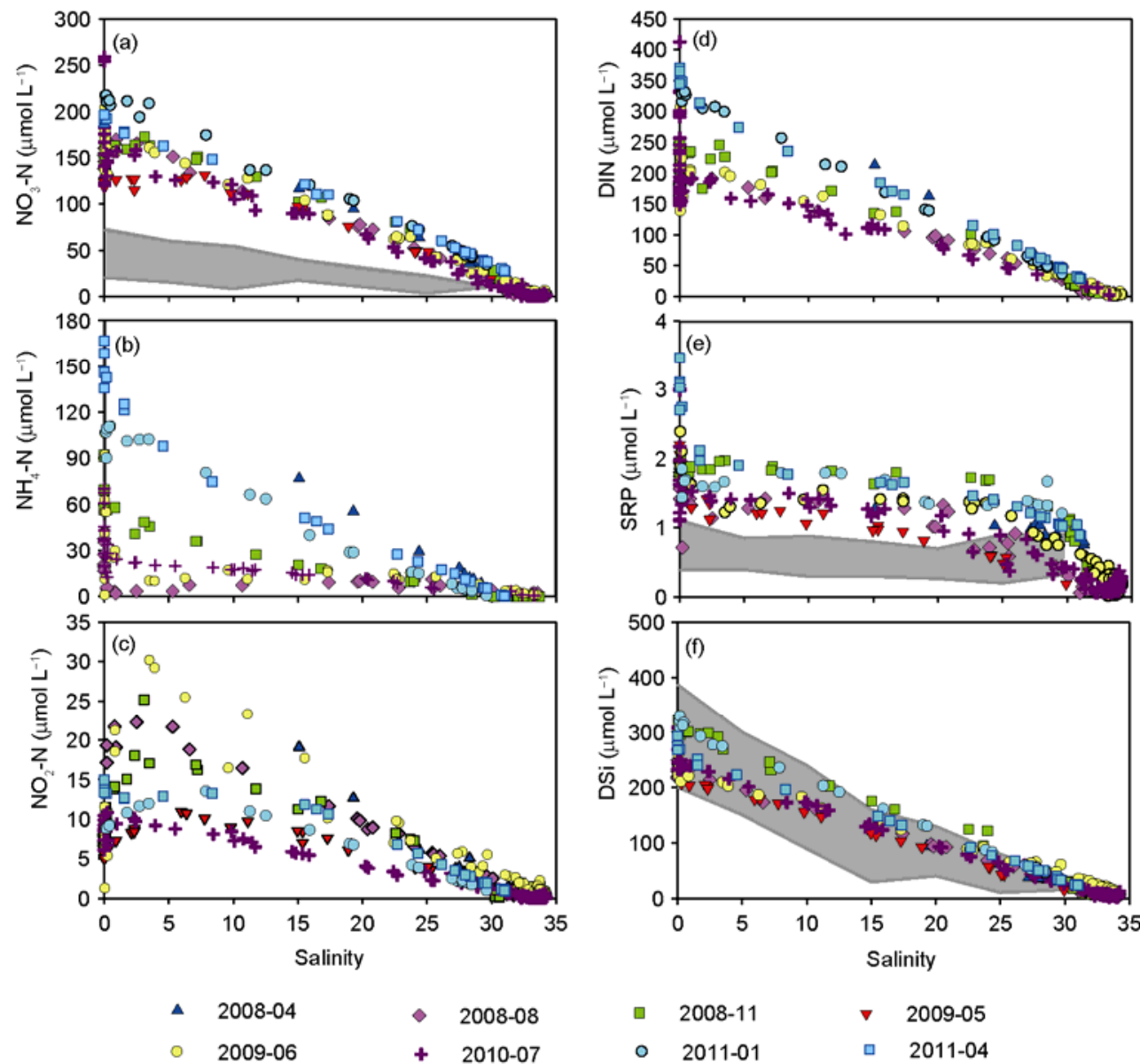

Figure 4 Relationship between nutrient concentrations and salinity in the JRE. All depth data and coastal data are included. Shaded areas show ranges of historical data [19-31].

level (Table 1).

\subsection{Relationship between nutrients and salinity in JRE}

Figure 4 plots nutrient concentrations against salinity in the JRE. Depth data suggest that the mixing behaviors of nutrients in surface and near-bottom waters were similar.

Both $\mathrm{NO}_{3}-\mathrm{N}$ and DSi demonstrated conservative mixing behaviors in the JRE, which were mainly controlled by tidal mixing. The relationship of $\mathrm{NO}_{3}-\mathrm{N} / \mathrm{DSi}$ concentrations against salinity was generally stable during wet seasons (Figure 4(a),(f)).

The relationship between $\mathrm{NH}_{4}-\mathrm{N}$ and salinity was complicated. In dry seasons, $\mathrm{NH}_{4}-\mathrm{N}$ demonstrated a conservative mixing behavior, whereas a significant removal was evidenced in the low-/mid-salinity area during wet seasons (Figure 4(b)). Correspondingly, $\mathrm{NO}_{2}-\mathrm{N}$ showed a clear addition in the same region during wet seasons (Figure 4(c)). Therefore, some degree of nitrification may occur in the upper/middle parts of the JRE, which needs further investigation. The salinity distribution of DIN was similar to $\mathrm{NO}_{3}-\mathrm{N}$ (Figure 4(a),(d)). This is obviously because the concentrations of $\mathrm{NO}_{3}-\mathrm{N}$ were generally higher than $\mathrm{NH}_{4}-\mathrm{N}$ and $\mathrm{NO}_{2}-\mathrm{N}$ in the JRE (Figure 4(a)-(c)).

The salinity distribution pattern of SRP in the JRE was much different from the other nutrients. In the area of salinity $<25$, SRP concentrations remained relatively stable (Figure 4(e)). This demonstrates a typical estuarine buffering effect on SRP, which has been reported in the JRE [27,31] and is usually attributed to absorption-desorption processes on suspending/sinking particles [37,38]. In the high salinity region, however, SRP was quickly diluted by relatively oligotrophic near-shore seawaters (Figure 4(e)).

To sum up, strong tidal mixing serves as the controlling factor for spatial distributions of most nutrient species in the JRE [20,27,39]. However, SRP was mainly controlled by the absorption-desorption processes on suspending/sinking particles [37]. Based on the SRP-salinity relationship (Figure 4(e)), a significant addition to SRP can be identified in the JRE.

\subsection{Characteristics and decadal changes of JRE nutrients}

The watershed of the Jiulong River is mainly composed of igneous rocks. Thus, chemical weathering is aluminosili- 
cate-based, and riverine DSi transport is remarkable. Therefore, DSi concentration in the river is 1-2 times higher than in the Yangtze River. Both DIN and SRP in the JRE upper reach were also 1-2 times higher than in the Yangtze Estuary. Thus, the N:P ratio in the JRE (100-150) was similar to or slightly higher than the ratio in the Yangtze Estuary (50-150) [40]. In the JRE upper reach, $\mathrm{NO}_{3}-\mathrm{N}$ accounted for $55 \%-72 \%$ of DIN in dry seasons, and $67 \%-96 \%$ in wet seasons (Table 1, Figure 4). This indicates that most DIN in the JRE may result from chemical fertilizer application [33] and soil erosion in the watershed. This phenomenon is similar to the Yangtze [41], but it is different from the upper reach of the Pearl River Estuary of China. The latter is significantly impacted by municipal sewage from Guangzhou, where $\mathrm{NH}_{4}-\mathrm{N}$ is the dominant chemical species of DIN [35].

Figure 4(a), (e) and (f) also summarizes the historical datasets of $\mathrm{NO}_{3}-\mathrm{N}, \quad \mathrm{SRP}$ and DSi collected during 1982-1997. In addition, Figure 4(f) includes a dataset from 1962 [19]. In the area of salinity $<25, \mathrm{NO}_{3}-\mathrm{N}$ concentrations from this study were 2-3 times higher than the historical data, while SRP was $0.5-1.0 \mu \mathrm{mol} \mathrm{L}{ }^{-1}$ higher than those historical data. In the high-salinity areas, however, their levels were similar to the historical data. These decadal changes of $\mathrm{N}$ and $\mathrm{P}$ in the upper/middle areas of the JRE are similar to the Yangtze and Mississippi. Undoubtedly, they are largely due to the increase (6-10 times) in chemical fertilizer application in the Jiulong watershed since 1978. They may also partially result from the rapid changes of land use and land cover in the watershed since late 1990s [17]. According to a study in Maryland, USA, urban streams have lower $\mathrm{NO}_{3}-\mathrm{N}$ concentrations $\left(0-280 \mu \mathrm{mol} \mathrm{L}{ }^{-1}\right)$ than streams draining agricultural watersheds $\left(70-1000 \mu \mathrm{mol} \mathrm{L}{ }^{-1}\right)$, but higher than streams draining forest watersheds $(\sim 70 \mu \mathrm{mol}$ $\mathrm{L}^{-1}$ ) [12]. In the upper reach of the JRE, $\mathrm{NO}_{3}-\mathrm{N}$ concentrations in the 1990 s were very similar to streams draining forest watersheds in Maryland (Figure 4(a)). However, after the construction of numerous cascade hydropower stations [15] and a significant increase in built lands [17] in the Jiulong watershed since late 1990s, forest areas accordingly decreased and thus the soil retention of N/P nutrients declined. Monitoring data have shown that concentrations of $\mathrm{NH}_{4}-\mathrm{N}$ increased in the river over the past decade [17]. Therefore, the link between growing human activities including land-use/land-cover changes and JRE nutrient variations is a worthy topic for further investigation.

Figure 4(f) shows that DSi distribution has remained nearly constant in the JRE since 1962. This is much different from the Yangtze, Mississippi and many other large rivers in which DSi largely declined over past decades [3-7]. A possible explanation is that the numerous hydropower stations along the Jiulong River are typically small and regulated daily [16]. Therefore, both flushing time and chemical weathering have changed relatively little over the past
50 years.

It is worthy noting that we observed a significant algal bloom in the JRE during February 2009, and it had certain influences on nutrients within the salinity range from 12 to 27 (data were not reported). Thus far, however, both the frequency and influences of algal blooms/red tides are insignificant in the JRE. If N/P nutrients continue to be elevated in the estuary as shown in Figure 4, more algal blooms/red tides may occur and strongly affect nutrient dynamics. This is worth further investigation.

\section{Flux estimation}

The estuary is not only a passage for transporting materials, but is also a reactor. Many estuarine biogeochemical processes significantly affect the formation and fluxes of materials under their transport from land to sea $[42,43]$. Therefore, it is important to distinguish riverine fluxes (into the estuary) from export fluxes (from the estuary into the sea). This is essential for better estimation of estuarine transport fluxes of nutrients, and for correct assessment of their impacts on coastal ecosystems.

\subsection{Riverine nutrient fluxes into JRE}

Based on nutrient concentrations of the freshwater endmembers (Table 1), and on the assumption that the nutrients remained in a steady state during the week of investigation, we use eq. (1) to calculate the riverine fluxes of nutrients into the estuary:

$$
F_{j}=C_{j} \times Q_{j},
$$

where $F_{j}$ is the flux of a nutrient species during the week under investigation; $C_{j}$ is concentration in the freshwater end-member (the relative deviations of surface and bottom nutrient concentrations at upstream stations were usually less than $10 \%) ; Q_{j}$ is the mean water discharge during the week under investigation.

By plotting $F_{j}$ against $Q_{j}$, and by fitting a linear regression equation with zero intercept, we obtain a simplified relationship between water discharge and riverine fluxes of any nutrient species into the estuary, as eq. (2):

$$
F_{j}=a \times Q_{j},
$$

where $a$ is a proportional coefficient corresponding to the water discharge weighted mean concentration of relevant freshwater end-member values. If we use the weekly mean water discharge $Q_{i}$, the nutrient flux of any week in the study period $\left(F_{i}\right)$ is predicted by

$$
F_{i}=a \times Q_{i} .
$$

By summing up all weekly nutrient fluxes over a year through eq. (4), the yearly riverine flux of a given nutrient species is obtained.

$$
F_{\text {year }}=\left(\sum_{i=1}^{52} F_{i}\right) / 52 .
$$


Table 2 shows calculated results based on eq. (1). Riverine fluxes of nutrients into the estuary showed significant seasonal variations (Table 2). For most nutrient species other than $\mathrm{NH}_{4}-\mathrm{N}$, the highest riverine fluxes occurred during the July 2010 cruise; the lowest were found during both the November 2008 and May 2009 cruises. The highest riverine flux of $\mathrm{NH}_{4}-\mathrm{N}$ was during the April 2011 cruise, followed by the July 2010 and January 2011 cruises.

Based on the dataset shown in Table 2, the linear regression equations (with zero intercept) of riverine fluxes against water discharge were: $F_{\mathrm{DIN}}=0.238 \times Q \quad\left(R^{2}=0.80\right)$; $F_{\mathrm{SRP}}=0.00197 \times Q\left(R^{2}=0.80\right) ; F_{\mathrm{DSi}}=0.252 \times Q\left(R^{2}=0.96\right)$. Figure 5(a)-(c) shows weekly riverine flux time series of DIN,
SRP and DSi, respectively. Also plotted are real data from Table 2. By comparing Figure 5(a)-(c) with Figure 2, a synchronous change between riverine nutrient fluxes and water discharge is clearly revealed. This suggests that the riverine nutrient fluxes were dominated by water discharge. Similar results have been reported in the Yangtze River and the Yellow River Estuary [44,45].

Based on Figure 5 and eq. (4), and using water discharge data during 2009-2010, we calculated yearly fluxes in the two years. And then the two-year mean riverine nutrientfluxes were estimated at $34.3 \times 10^{3} \mathrm{t} \mathrm{N} \mathrm{a}^{-1}, 0.63 \times 10^{3} \mathrm{t} \mathrm{P}$ $\mathrm{a}^{-1}$, and $72.7 \times 10^{3} \mathrm{t} \mathrm{Si} \mathrm{a}^{-1}$. We used these two-year mean fluxes as annual mean fluxes during the period of investigation.

Table 2 Riverine nutrient flux estimation for individual cruises

\begin{tabular}{|c|c|c|c|c|c|c|c|}
\hline \multirow{2}{*}{ Cruise } & \multirow{2}{*}{$Q_{j}\left(\mathrm{~m}^{3} \mathrm{~s}^{-1}\right)$} & \multicolumn{6}{|c|}{ Riverine nutrient flux $\left(\mathrm{mol} \mathrm{s}^{-1}\right)$} \\
\hline & & $\mathrm{NO}_{3}-\mathrm{N}$ & $\mathrm{NO}_{2}-\mathrm{N}$ & $\mathrm{NH}_{4}-\mathrm{N}$ & DIN & SRP & DSi \\
\hline 2008-04 & $436^{\text {a) }}$ & N/A & N/A & N/A & N/A & N/A & N/A \\
\hline 2008-08 & $589^{\mathrm{a})}$ & 92.2 & 4.0 & 21.4 & 117.6 & 1.10 & 137.5 \\
\hline 2008-11 & $177^{\mathrm{a})}$ & 27.0 & 1.2 & 12.2 & 40.5 & 0.32 & 54.1 \\
\hline 2009-05 & $231^{\mathrm{b})}$ & 28.6 & 1.2 & N/A & N/A & 0.48 & 55.2 \\
\hline 2009-06 & $431^{\mathrm{b})}$ & 74.9 & 3.5 & 17.8 & 96.2 & 1.03 & 103.6 \\
\hline $2010-07$ & $1048^{\text {b) }}$ & 183.2 & 9.2 & 43.3 & 235.7 & 1.89 & 257.2 \\
\hline 2011-01 & $384^{\mathrm{b})}$ & 83.3 & 3.4 & 37.7 & 124.4 & 0.63 & 120.3 \\
\hline 2011-04 & $389^{\text {b) }}$ & 73.7 & 5.6 & 60.9 & 140.2 & 1.28 & 110.8 \\
\hline
\end{tabular}

a) Monthly mean water discharge during 1961-2006 [14]; b) weekly mean water discharge during the cruises; N/A means no data.
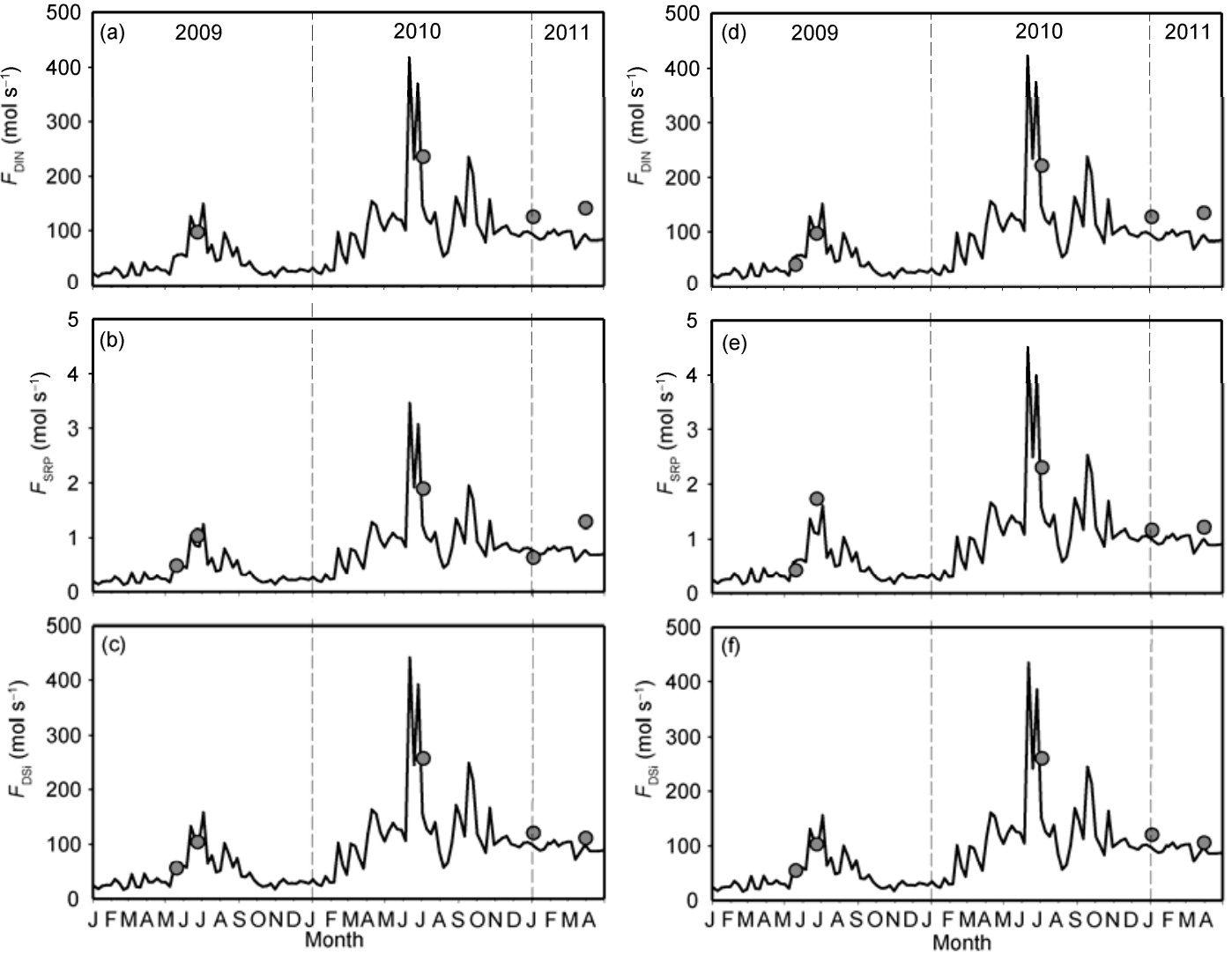

Figure 5 Time series of riverine fluxes ((a)-(c)) and seaward export fluxes ((d)-(f)) of DIN, SRP and DSi, during $2009-2011$. 


\subsection{Export fluxes of nutrients from JRE into the sea}

Here we used two independent methods, one to calculate nutrient export fluxes from the JRE into the sea, and the other to estimate the addition flux of the non-conservative nutrient species-SPR. The latter was defined as the nonconservative flux by reference [43].

(1) Using effective concentration method to estimate estuarine export fluxes. First, we analyzed Figure 4 again and extrapolated the linear regression curves of nutrient concentrations against salinity, from the middle/high salinity areas to zero salinity. Given a nutrient species under investigation, the suppositional nutrient concentration at the freshwater end-member was defined as the estuarine export effective concentration of the nutrient species $\left(C_{\mathrm{o}}^{*}\right)$ [46]. Then, the export flux of the nutrient species from the JRE into the sea can be obtained by $F=C_{\mathrm{o}}{ }^{*} \times Q$.

Table 3 summarizes the estuarine export effective concentrations in the JRE for every cruise. The effective concentration ranges of DIN, SRP and DSi were 174-390, 1.8-5.9, and 217-312 $\mu \mathrm{mol} \mathrm{L}^{-1}$, respectively. By comparing Tables 3 and 1, the estimated estuarine export effective concentrations of DIN and DSi were nearly identical to the observed nutrient concentrations at the freshwater end-members. However, the estuarine export effective concentrations of SRP were 1-2 times greater than the freshwater end-member concentrations. A possible explanation for this phenomenon is that re-suspended particles release additional SRP. Similar to previous analyses for riverine fluxes, the seasonal variations of estuarine export effective concentrations of DIN, SRP and DSi were much smaller than seasonal variations of water discharge. Therefore, we can calculate the export fluxes from the JRE into the sea via a similar procedure for riverine flux estimation (Section 3.1). The results are also listed in Table 3.

Based on the datasets shown in Tables 2 and 3, the linear regression equations (with zero intercept) of estuarine export fluxes against water discharge were: $F_{\mathrm{DIN}}=0.241 \times Q$ $\left(R^{2}=0.65\right) ; F_{\mathrm{SRP}}=0.00257 \times Q \quad\left(R^{2}=0.55\right) ; F_{\mathrm{DSi}}=0.248 \times Q \quad\left(R^{2}\right.$ $=0.96)$. Based on Figure 2 and an equation similar to eq. (3), we extrapolated limited estuarine export flux data of DIN, SRP and DSi to every week of the study period (Figure 5(d)-(f)). Time series of the estuarine export fluxes of nu- trients were also dominated by water discharge. The annual mean estuarine export fluxes of DIN, SRP and DSi were estimated at $34.8 \times 10^{3} \mathrm{t} \mathrm{N} \mathrm{a}^{-1}, 0.82 \times 10^{3} \mathrm{t} \mathrm{P} \mathrm{a}^{-1}$ and $71.6 \times 10^{3}$ $\mathrm{t} \mathrm{Si} \mathrm{a}^{-1}$, respectively, during the investigation period.

(2) Non-conservative flux estimation for SRP. To examine the applicability of the aforementioned effective concentration method to the non-conservative chemical species SRP, we used the LOICZ Nutrient Budget Model $[47,48]$ to estimate the biogeochemical modification of SRP in the JRE. In principle, based on the law of conservation of mass, mass balances of water/salt and biogenic elements are initially established in an estuary. Then, relevant fluxes of the targeted biogeochemical element are estimated [33,43].

The mass balance of water was established for the JRE (Figure 6). According to this figure, the residual water flux exported from the estuary into the adjacent coastal zone is $V_{\mathrm{R}}=-V_{\mathrm{Q}}-V_{\mathrm{P}}-V_{\mathrm{O}}+\left|V_{\mathrm{E}}\right|$, where $V_{\mathrm{Q}}, V_{\mathrm{P}}, V_{\mathrm{O}}$, and $V_{\mathrm{E}}$ refer to water discharge, precipitation, other freshwater input, and evaporation, respectively. The exchange flux between estuary and sea is called $V_{\mathrm{X}}$.

Since there are neither inner sources nor inner sinks of water and salt in the estuary system, i.e. $\sum$ input $=\sum$ output, we have

$$
\begin{gathered}
V_{\mathrm{Q}}+V_{\mathrm{P}}+V_{\mathrm{O}}+V_{\mathrm{R}}+V_{\mathrm{X}}=\left|V_{\mathrm{E}}\right|+V_{\mathrm{X}}, \\
V_{\mathrm{Q}} \times V_{\mathrm{Q}}+V_{\mathrm{P}} \times S_{\mathrm{P}}+V_{\mathrm{O}} \times S_{\mathrm{O}}+V_{\mathrm{R}} \times S_{\mathrm{R}}+V_{\mathrm{X}} \times S_{\mathrm{ocn}}=\left|V_{\mathrm{E}}\right| \times S_{\mathrm{E}}+V_{\mathrm{X}} \times S_{\mathrm{sys}},
\end{gathered}
$$

where $S_{\mathrm{Q}}, S_{\mathrm{P}}, S_{\mathrm{O}}, S_{\mathrm{E}}, S_{\mathrm{R}}$ and $S_{\mathrm{ocn}}$ are average salinities of individual components. $S_{\mathrm{Q}}, S_{\mathrm{P}}, S_{\mathrm{O}}, S_{\mathrm{E}}$ are assumed to be zero. The salinity of outflow exchange $S_{\mathrm{X}}$ is usually the same as

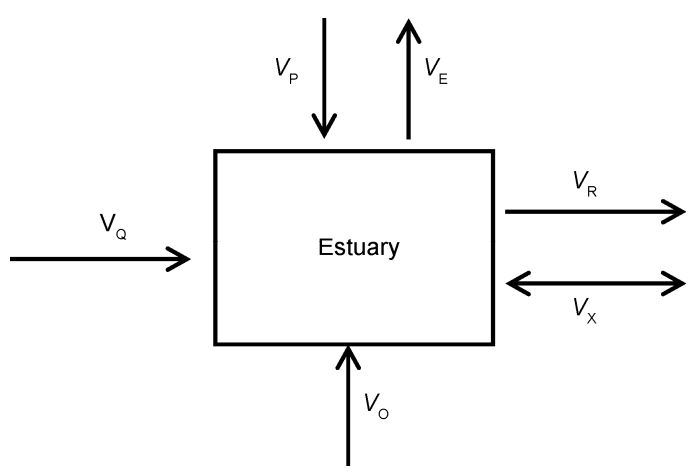

Figure 6 Mass balance of water in an estuary (modified from $[47,48]$ ).

\begin{tabular}{|c|c|c|c|c|c|c|}
\hline Cruise & $C_{\mathrm{DIN}}{ }^{*}$ & $C_{\text {SRP }}{ }^{*}$ & $C_{\mathrm{DSi}}{ }^{*}$ & $F_{\text {DIN }}$ & $F_{\text {SRP }}$ & $F_{\mathrm{DSi}}$ \\
\hline 2008-04 & 390 & 2.2 & 217 & 170.0 & 0.96 & 94.6 \\
\hline 2008-08 & 191 & 2.6 & 230 & 112.5 & 1.53 & 135.5 \\
\hline 2008-11 & 239 & 5.9 & 309 & 42.3 & 1.04 & 54.7 \\
\hline $2009-05$ & 174 & 1.8 & 231 & 40.2 & 0.42 & 53.4 \\
\hline 2009-06 & 223 & 4.0 & 237 & 96.1 & 1.72 & 102.1 \\
\hline $2010-07$ & 211 & 2.2 & 248 & 221.1 & 2.31 & 259.9 \\
\hline 2011-04 & 344 & 3.1 & 270 & 133.8 & 1.21 & 105.0 \\
\hline
\end{tabular}

Table 3 Estimation of estuarine export effective concentrations $\left(\mu \mathrm{mol} \mathrm{L} \mathrm{L}^{-1}\right)$ and seaward export fluxes $\left(\mathrm{mol} \mathrm{s}^{-1}\right)$ during every cruise ${ }^{\text {a) }}$

a) Water discharge data refer to Table 2 . 
$S_{\text {sys }}$, whereas the salinity of inflow exchange is usually the average salinity of the adjacent sea $S_{\text {ocn. }}$. The average of $S_{\text {sys }}$ and $S_{\text {ocn }}$ was assigned salinity of the residual flow (i.e. $S_{R}$ ) $[33,48]$.

Based on eqs. (5) and (6), the exchange flux $V_{\mathrm{X}}$ can be obtained as

$$
V_{\mathrm{X}}=\frac{V_{\mathrm{R}} \times S_{\mathrm{R}}}{S_{\text {sys }}-S_{\text {ocn }}} .
$$

For the non-conservative chemical species SRP, its nonconservative flux is defined as $\Delta \mathrm{SRP}=\sum$ output $-\sum$ input. Therefore,

$$
\begin{aligned}
\Delta \mathrm{SRP} & =V_{\mathrm{R}} \times \mathrm{SRP}_{\mathrm{R}}+\left|V_{\mathrm{E}}\right| \times \mathrm{SRP}_{\mathrm{E}}-V_{\mathrm{Q}} \times \mathrm{SRP}_{\mathrm{Q}}-V_{\mathrm{O}} \times \mathrm{SRP}_{\mathrm{O}}-V_{\mathrm{P}} \times \mathrm{SRP}_{\mathrm{P}} \\
& -V_{\mathrm{X}} \times\left(\mathrm{SRP}_{\text {ocn }}-\mathrm{SRP}_{\text {sys }}\right) .
\end{aligned}
$$

If we ignore evaporation, precipitation and other freshwater input, eq. (8) can be simplified as

$$
\Delta \mathrm{SRP}=V_{\mathrm{R}} \times \mathrm{SRP}_{\mathrm{R}}-V_{\mathrm{X}} \times\left(\mathrm{SRP}_{\text {ocn }}-\mathrm{SRP}_{\text {sys }}\right)-V_{\mathrm{Q}} \times \mathrm{SRP}_{\mathrm{Q}} .
$$

All calculation procedures and intermediate results are shown in Table 4. If $\triangle \mathrm{SRP}$ is positive, SRP is added by the system. Otherwise, SRP is removed from the system [48].

As shown in Table 4, SRP was generally added in the JRE. The highest $\Delta$ SRP was $0.58 \mathrm{~mol} \mathrm{~s}^{-1}$ in July 2010 , and the second highest $\Delta \mathrm{SRP}$ was $0.32 \mathrm{~mol} \mathrm{~s}^{-1}$ in August 2008 . Low $\triangle$ SRP levels between 0.06 and $0.18 \mathrm{~mol} \mathrm{~s}^{-1}$ were obtained in dry seasons.

Based on real-time water discharge and the $\triangle \mathrm{SRP}$ data shown in Tables 2 and 4, the linear regression equation (with zero intercept) of non-conservative fluxes of SRP against weekly water discharge is obtained: $\Delta \mathrm{SRP}=0.000507 \mathrm{x}$ $Q\left(R^{2}=0.92\right)$. From a similar procedure to Section 3.1, we obtained a mean non-conservative SRP flux of $0.16 \times 10^{3} \mathrm{t} \mathrm{a}^{-1}$.

(3) Comparison between riverine fluxes and estuarine export fluxes. Table 5 summarizes the nutrient flux estimation. It is clear that the riverine DIN and DSi fluxes were equal to the estuarine export fluxes (relative deviation $<2 \%$ ). This is obviously because both DIN and DSi were conservatively mixed in the estuary (Figure 4(d),(f)). However, since SRP is a non-conservative chemical species in the JRE (Figure 4(e)), its estuarine export flux was 30\% higher than the riverine SRP flux (Table 5). Based on the mass balance method, we obtained the additional flux of SRP at $0.16 \times 10^{3} \mathrm{t} \mathrm{a}^{-1}$ in the JRE (Section 3.2). If we add the addi- tional SRP flux to the SRP riverine flux (Section 3.1), a SRP flux of $0.79 \times 10^{3} \mathrm{t} \mathrm{a}^{-1}$ is obtained. This value is very close to the estuarine export flux of SRP $\left(0.82 \times 10^{3} \mathrm{t} \mathrm{a}^{-1}\right)$ estimated via the estuarine export effective concentration (Section 3.2). Therefore, the above-estimated fluxes of SPR are all reasonable.

\subsection{Significance of nutrient fluxes from Jiulong River}

We calculated the areal yield rates of DIN, SRP and DSi from the Jiulong River based on the riverine fluxes (Table 5) and the watershed area datum. These rates were $2.3 \times 10^{3} \mathrm{~kg}$ $\mathrm{N} \mathrm{km}^{-2} \mathrm{a}^{-1}\left(1.7 \times 10^{3} \mathrm{~kg} \mathrm{~N} \mathrm{~km}^{-2} \mathrm{a}^{-1}\right.$ for $\left.\mathrm{NO}_{3}-\mathrm{N}\right), 42 \mathrm{~kg} \mathrm{P} \mathrm{km}^{-2}$ $\mathrm{a}^{-1}$ and $4.8 \times 10^{3} \mathrm{~kg} \mathrm{Si} \mathrm{km}^{-2} \mathrm{a}^{-1}$. As shown in Figure 7, the areal yield rate of $\mathrm{NO}_{3}-\mathrm{N}$ from the river was very high compared to major world rivers. Although it was lower than the Ganges and Danshui Rivers, which are in tropical and/or subtropical Asia, their human $\mathrm{NO}_{3}-\mathrm{N}$ productivities per person are at similarly high levels (Figure 7). We make comparisons to several large rivers in China [41], as follows. Although water discharge of the Jiulong River is only $1.1 \%$ that of the Yangtze River, 2.5\% that of the Pearl River, and $21.8 \%$ that of the Minjiang River (Fujian Province, China), areal DIN and SRP yield rates from the Jiulong River

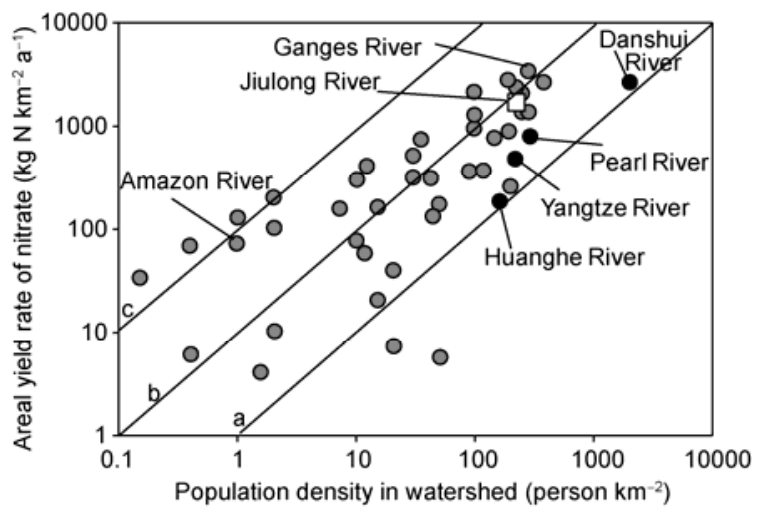

Figure 7 Relationship between areal $\mathrm{NO}_{3}-\mathrm{N}$ yield rates and population densities in major world river basins, modified from [49]. The Jiulong River is shown as open rectangle based on this study. Update data of Yangtze, Huanghe, Pearl and Danshui watershed are based on references [41,50]. Line a denotes $1 \mathrm{~kg} \mathrm{~N}_{\text {person }}{ }^{-1} \mathrm{a}^{-1}$; line $\mathrm{b} 10 \mathrm{~kg} \mathrm{~N}$ person ${ }^{-1} \mathrm{a}^{-1}$; and line c $100 \mathrm{~kg} \mathrm{~N}_{\text {person }}{ }^{-1} \mathrm{a}^{-1}$.

Table 4 Water excharge rates $V_{\mathrm{X}}\left(\mathrm{m}^{3} \mathrm{~s}^{-1}\right)$, SRP fluxes $\left(\mathrm{mol} \mathrm{s}^{-1}\right)$ and non-conservative fluxes of SRP $\left(\Delta \mathrm{SRP}\right.$, mol s$\left.{ }^{-1}\right)$ in the nutrient budget model for JRE ${ }^{\text {a) }}$

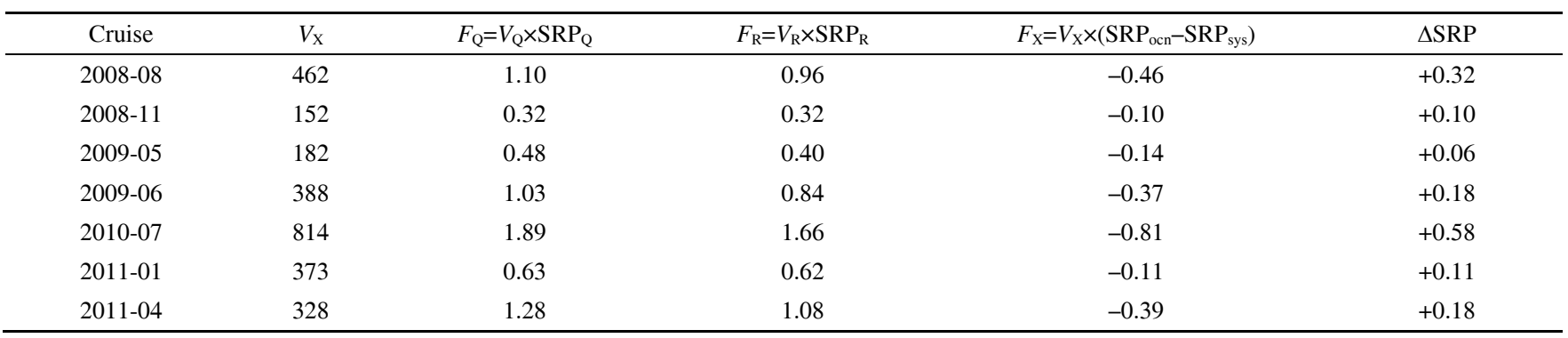

a) Negative values mean removal; positive values mean addition. 
Table 5 Summary of nutrient flux estimation in this study (Unit: $10^{3} \mathrm{ta}^{-1}$ )

\begin{tabular}{lccc}
\hline & $F_{\mathrm{DIN}}$ & $F_{\mathrm{SRP}}$ & $F_{\mathrm{DSi}}$ \\
\hline Riverine fluxes & 34.3 & 0.63 & 72.7 \\
$\begin{array}{l}\text { Estuarine export fluxes } \\
\text { (effective concentration method) }\end{array}$ & 34.8 & 0.82 & 71.6 \\
$\begin{array}{l}\text { Non-conservative flux } \\
\text { (mass balance method) }\end{array}$ & $\mathrm{N} / \mathrm{A}$ & 0.16 & $\mathrm{~N} / \mathrm{A}$ \\
\hline
\end{tabular}

watershed are respectively 4.1 and 7.1 times those from the Yangtze River watershed, 2.4 and 2.4 times those from the Pearl River watershed, and 3.1 and 1.7 times those from the Minjiang River watershed. Thus, potential influences of nutrients exported from the JRE should be seriously assessed when considering N/P budgets in the coastal zone of southeast China.

The areal yield rate of DSi in the Jiulong watershed is 1.9 times greater than that in the Yangtze basin and 0.7 times greater than that in the Pearl basin. This is consistent with the silicate-rich Jiulong geography. The neighboring Minjiang watershed (another medium-large river system in Fujian Province of China) is also characterized by a similar areal DSi yield rate of $5.0 \times 10^{3} \mathrm{~kg} \mathrm{Si} \mathrm{km}^{-2} \mathrm{a}^{-1}$ [41], owing to a similar regional geology and weathering background.

\section{Summary and implications}

This study illustrates the distribution, fluxes and decadal changes of nutrients in the subtropical Jiulong River Estuary (JRE) of southeast China, a strong tidal estuary heavily influenced by growing human activities over the last three decades. Quasi-conservative behavior was found for $\mathrm{NO}_{3}-\mathrm{N}$ and DSi in the JRE, both of which showed higher concentrations in the dry season than in the wet season for the freshwater end-member. The distribution of $\mathrm{NH}_{4}-\mathrm{N}$ has significant seasonal variation, demonstrating a conservative behavior in the dry season and removal in the wet season. In areas with salinity $<25$, SRP remains relatively stable $(1.0-$ $2.0 \mu \mathrm{mol} \mathrm{L}{ }^{-1}$ ), but is rapidly diluted by seawater in higher salinity zones.

Riverine DIN and DSi fluxes into the estuary were $34.3 \times 10^{3} \mathrm{t} \mathrm{N} \mathrm{a}^{-1}$ and $72.7 \times 10^{3} \mathrm{t} \mathrm{Si} \mathrm{a}^{-1}$, respectively, showing no marked differences from estuarine export fluxes into the sea (i.e. $34.8 \times 10^{3} \mathrm{t} \mathrm{N} \mathrm{a}^{-1}$ and $71.6 \times 10^{3} \mathrm{t} \mathrm{Si} \mathrm{a}^{-1}$ ). However, the estuarine export SRP flux into the sea was $30 \%$ higher than that entering the estuary, indicating significant SRP addition within the estuary. The areal yield rate of $\mathrm{NO}_{3}-\mathrm{N}$ in the Jiulong watershed is at the highest level compared with major world rivers.

Notably, both N/P concentrations and fluxes have increased over the past decade in this subtropical estuary, while both DSi level and flux have remained relatively stable. This finding is distinct from several other large Chinese river-estuarine systems that are controlled by similar influences of the East Asian monsoon and human activities. The Yellow River Estuary of North China shows simultaneous declines in water discharge [51] and nutrient fluxes. The Yangtze Estuary of East China shows increasing N/P fluxes and decreasing DSi flux [4-7], while its water discharge demonstrates no significant changes. It is not clear what mechanisms control this geographic variation in Chinese river-estuarine systems. This uncertainty calls for more investigation.

We thank Professors Shuh-Ji Kao, Nengwang Chen, Jinliang Huang and Weiran Pan for their constructive discussion and background materials. The crews of $R / V$ Ocean I, $R / V$ Ocean II and $R / V$ Yanping II provided much help during the sampling cruises. We are grateful to four anonymous reviewers for their constructive comments and suggestions on the manuscript. This work was supported by the National Natural Science Foundation of China (NSFC) (40810069004) and the National Basic Research Program of China (2009CB421204). Sampling cruises were partially supported by the State Oceanic Administration of China (contract DOMEPMEA-01-10) and the NSFC (40949901).

1 Billen G, Garnier J, Deligne C, et al. Estimates of early-industrial inputs of nutrients to river systems: Implication for coastal eutrophication. Sci Total Environ, 1999, 243/244: 43-52

2 Jickells T D. Nutrient biogeochemistry of the coastal zone. Science, 1998, 281: 217-222

3 Turner R E, Rabalais N N. Changes in Mississippi River water quality this century-Implications for coastal food webs. BioScience, 1991, 41: 140-147

4 Zhang J. On the critical issues of land-ocean interactions in coastal zones (in Chinese). Chin Sci Bull (Chin Ver), 2011, 56: 1956- 1966

5 Duan S-W, Xu F, Wang L-J. Long-term changes in nutrient concentrations of the Changjiang River and principal tributaries. Biogeochemistry, 2007, 85: 215-234

6 Li M-T, Xu K-Q, Watanabe M, et al. Long-term variations in dissolved silicate, nitrogen, and phosphorus flux from the Yangtze River into the East China Sea and impacts on estuarine ecosystem. Estuar Coast Shelf Sci, 2007, 71: 3-12

7 Li M-T, Cheng H-Q. Changes of dissolved silicate flux from the Changjiang River into sea and its influence since late 50 years (in Chinese). Chin Environ Sci, 2001, 21: 193-197

8 Liu K-K, Atkinson L, Quinones R A, et al. Biogeochemistry of continental margins in a global context. In: Liu $\mathrm{K} \mathrm{K}$, Atkinson L, Quinones R A, et al, eds. Carbon and Nutrient Fluxes in Continental Margins-A Global Synthesis. The IGBP Series. Heidelberg: Springer, 2010. 3-24

9 Justic D, Rabalais N N, Turner R E. Stoichiometric nutrient balance and origin of coastal eutrophication. Mar Pollut Bull, 1995, 30: 41-46

10 Díaz R J, Rosenberg R. Spreading dead zones and consequences for marine ecosystems. Science, 2008, 321: 926-929

11 Anderson D M. Turning back the harmful red tide. Nature, 1997, 388: 513-514

12 Kaushal S S, Groffman P M, Band L E, et al. Interaction between urbanization and climate variability amplifies watershed nitrate export in Maryland. Environ Sci Technol, 2008, 42: 5872-5878

13 Kaushal S S, Pace M L, Groffman P M, et al. Land use and climate variability amplify contaminant pulses. EOS Trans Am Geophys Union, 2010, 91: 221-222

14 Huang X Q. Hydrological characteristics in the Jiulong watershed (in Chinese). Sci Technol Water Resour, 2008, (1): 16-20

15 Meng D K. Thousands of minitype hydropower stations do harm to the Jiulong River, Fujian (in Chinese). Water Carriage Pearl River, 2011, (11): 44-47 
16 Zhu J-X. The influence of building Beixi hydropower station on the low water runoff of the main stream in backward position of Jiulong River (in Chinese). Chin Waterpower Electrif, 2007, (3): 7-10

17 Huang J L, Li Q S, Pontius R G, et al. Detecting the dynamic linkage between landscape characteristics and water quality in a subtropical coastal watershed, southeast China. Environ Manage, 2011, doi: 10. 1007/s00267-011-9793-2

18 Hong H S, Yang L Y, Guo W-D, et al. Characterization of dissolved organic matter under contrasting hydrologic regimes in a subtropical watershed using PARAFAC model. Biogeochemistry, 2011, doi: 10.1007/s10533-011-9617-8

19 Li F S, Wu Y D, Wang L F, et al. Physico-chemical processes of silicates in the estuary region, I. A preliminary investigation on the distribution and variation of reactive silicate content and the factors affecting them (in Chinese). Oceanol Limnol Sin, 1964, 6: 311-322

20 Chen S T, Ruan W Q, Zhang L P. Chemical characteristics of nutrient elements in the Jiulong Estuary and the calculation of its flux (in Chinese). Trop Oceanol, 1985, (4): 16-24

21 Ji W D, Huang S G, Wang W Q. Nitrate supplement at the Jiulongjiang River mouth (in Chinese). Mar Sci Bull, 1987, (2): 19-22

22 Hong H S, Dai M H, Chen S T. Distributions and transformation of different phosphorus forms in Jiulong River Estuary and Xiamen Harbor in spring (in Chinese). Mar Environ Sci, 1989, (2): 1-8

23 Hong H S, Lin J. Preliminary study on the distribution of nutrients, organic matter, trace metals in sea surface microlayer in Xiamen Bay and Jiulong Estuary. Acta Oceanol Sin, 1990, (1): 81-90

24 Chen S T. Relation between inorganic nitrogen and phosphorus in Jiulongjiang Estuary and western Xiamen Harbor (in Chinese). Mar Sci Bull, 1993, (5): 26-32

25 Chen S-T, Wu L-Y, Wu J-W. Distribution of chemical species of phosphorus in Jiulong River Estuary area (in Chinese). Trop Oceanol, 1994, (1): 69-75

26 Chen S, Liao W-Z, Luo B-K, et al. Transfer and input of phosphorus from Jiulong Estuary (in Chinese). J Oceanogr Taiwan Strait, 1996, 15: $137-142$

27 Yang Y-P, Hu M-H. Biogeochemistry in the Jiulong River Estuary (in Chinese). In: Zhang J, ed. Biogeochemistry in Chinese Major Estuaries-Transferring of Chemical Matters and Their Environments. Beijing: Ocean Press, 1996. 54-57

28 Chen S M, Lu M L, Fu T B. Behaviors of various phosphorus forms in Jiulongjiang estuarine water (in Chinese). J Oceanogr Taiwan Strait, 1997, 16: 299-305

29 Chen S, Liao W Z, Xu A Y. Transfer of phosphorus in Jiulongjiang Estuarine water, 1995 cruises (in Chinese). J Oceanogr Taiwan Strait, 1998, 17: 71-75

30 Yang Y P, Hu M H, Chen $\mathrm{H} \mathrm{L}$, et al. Behaviours and flux of bioavailable phosphorus in Jiulongjiang Estuary (in Chinese). J Oceanogr Taiwan Strait, 1998, 17: 269-274

31 Zhang Y H, Wang W Q, Huang Z Q. Salinity fronts and chemical behaviour of nutrient in Jiulongjiang Estuary (in Chinese). Mar Environ Sci, 1999, (4): 1-7

32 Cai A Z, Cai Y E, Zhu X N, et al. Diffusion and modern sedimentation of seaward-transporting discharges in the estuary of Jiulongjiang River, Fujian Province (in Chinese). Mar Geol Quat
Geol, 1991, 11: 57-67

33 Cao W Z, Hong H S, Yue S P. Modelling agricultural nitrogen contributions to the Jiulong River estuary and coastal water. Glob Planet Change, 2005, 47: 111-121

34 US EPA. Sample preservation. In: USEPA, ed. Methods for Chemical Analysis of Water and Wastes, EPA-600/4-79-020, 1983. xv-xx

35 Dai M H, Wang L F, Guo X H, et al. Nitrification and inorganic nitrogen distribution in a large perturbed river/estuarine system: The Pearl River estuary, China. Biogeosciences, 2008, 5: 1227-1244

36 Pai S C, Tsau Y J, Yang T I. pH and buffering capacity problems involved in the determination of ammonia in saline water using the idophenol blue spectrophotometric method. Analyt Chim Acta, 2001, 434: 209-216

37 Froelich P N, Bender M L, Luedtke N A. The marine phosphorus cycle. Am J Sci, 1982, 282: 474-511

38 van der Zee C, Roevros N, Chou L. Phosphorus speciation, transformation and retention in the Scheldt estuary (Belgium/The Netherlands) from the freshwater tidal limits to the North Sea. Mar Chem, 2007, 106: 76-91

39 Wang W Q, Huang S G, Gu D Y, et al. Mixing characters of fresh water with sea water in the Jiulongjiang Estuary, Fujian (in Chinese). J Oceanogr Taiwan Strait, 1986, 5: 10-17

40 Chai C, Yu Z-M, Shen Z-L, et al. Nutrient characteristics in the Yangtze River estuary and the adjacent East China Sea before and after impoundment of the Three Gorges Dam. Sci Total Environ, 2009, 407: 4687-4695

41 Liu S M, Hong G H, Zhang J, et al. Nutrient budgets for large Chinese estuaries. Biogeosciences, 2009, 6: 2245-2263

42 Zhang J. Nutrient elements in large Chinese estuaries. Cont Shelf Res, 1996, 16: 1023-1045

43 Shen H-T. Material Fluxes in the Changjiang Estuary (in Chinese). Beijing: Ocean Press, 2001. 137-153

44 Shen Z L. Preliminary study on the Changjiang River mainstream nutrients fluxes (in Chinese). Oceanol Limnol Sin, 1997, 28: 522-528

45 Yao Q Z, Yu Z G, Wang T, et al. Effect of the first water-sediment regulation on the variations of dissolved inorganic nutrients' concentrations and fluxes in the lower main channel of the Yellow River (in Chinese). Environ Sci, 2009, 30: 3534-3540

46 Officer C B. Discussion of the behaviour of nonconservative dissolved of constituents in estuaries. Estuar Coast Mar Sci, 1979, 9: 91-94

47 Pernetta J C, Milliman J D. LOICZ Implementation Plan. IGBP Report No.33, Stockholm, 1995

48 Gordon D C, Boudreau P R, Mann K H, et al. LOICZ Biogeochemical Modeling Guidelines. LOICZ/R\&S/95-5, 1996

49 Peierls B L, Caraco N F, Pace M L, et al. Human influence on river nitrogen. Nature, 1991, 350: 386-387

50 Wen L S, Jiann K-T, Liu K-K. Seasonal variation and flux of dissolved nutrients in the Danshuei Estuary, Taiwan: A hypoxic subtropical mountain river. Estuar Coast Shelf Sci, 2008, 78: 694-704

51 Wang H J, Yang Z-S, Saito Y, et al. Interannual and seasonal variation of the Huanghe (Yellow River) water discharge over the past 50 years: Connections to impacts from ENSO events and dams. Glob Planet Change, 2006, 50: 212-225

Open Access This article is distributed under the terms of the Creative Commons Attribution License which permits any use, distribution, and reproduction in any medium, provided the original author(s) and source are credited. 